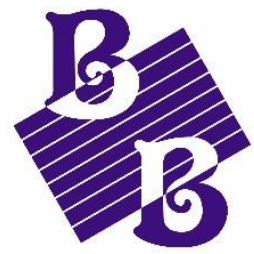

Biobacta

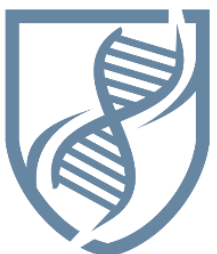

Journal of Bioscience and Applied Research WWW.JBAAR.ORG

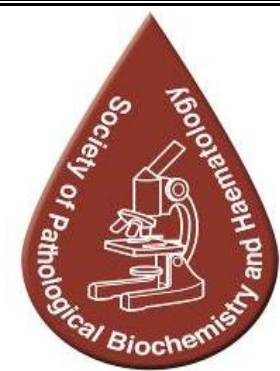

\title{
Effect of discharged sewage water on accumulation of heavy metals in three plant species Zygophyllum album L. Suaeda aegyptiaca and Cyprus rotundus
}

\author{
Al-Zahrani Saeed, AL-Hasawi Zaki \\ Department of Biological Sciences, Faculty of Science, King Abdul Aziz University, Jeddah, Saudi \\ Arabia \\ DOI: 10.21608/jbaar.2017.126145
}

\begin{abstract}
This study was conducted to evaluate pollution caused by Jeddah City sewage water discharge on the Red Sea coastal soil and the accumulation of heavy metals in the naturally growing plants: Suaeda aegyptiaca Forssk. , Zygophyllum album L. and Cypersus jeminicus Rottb. Metal accumulation in the polluted water, soil, and plants was compared with those parameters in an unpolluted coastal site, $30 \mathrm{~km}$ south of Jeddah City. The results indicated a significantly high accumulation of metals in seawater, soil, and plants of the polluted site compared to the unpolluted site. Macro - elements $\mathrm{Ca}, \mathrm{Na}, \mathrm{Mg}, \mathrm{K}$ and $\mathrm{P}$, and microelements (a heavy and toxic metal ) especially $\mathrm{Fe}, \mathrm{Al}, \mathrm{Zn}$, and $\mathrm{Mn}$ were significantly high dominating all other elements. The three species differed in the elements they accumulated, and all of them accumulated more than one element. The different plant parts (leaves, stems, roots ) differed in the magnitude of the metals they accumulated. Suaeda aegyptiaca Forssk. accumulated 7 elements $\mathrm{Zn}, \mathrm{Cu}, \mathrm{Mn}, \mathrm{Cr}, \mathrm{Ni}, \mathrm{Ba}$, Al, and Zygophyllum album L. accumulated 9 elements, $\mathrm{Zn}, \mathrm{Mn}, \mathrm{Cu}, \mathrm{Ag}, \mathrm{Co}, \mathrm{Al}, \mathrm{Ba}, \mathrm{Ni}$, and $\mathrm{Cr}$, while Cyperus jeminicus Rottb. accumulated only 3 elements, $\mathrm{Zn}, \mathrm{Mn}$, and $\mathrm{Ag}$. These three species may be considered hyperaccumulators to $\mathrm{Zn}, \mathrm{Ni}$, and Al metals. According to this study, these three species can be used as phytoremediation to soils polluted with heavy metals.
\end{abstract}

Key Words, Sewage water, Suaeda aegyptiaca Forssk. , Zygophyllum album L. and Cypersus jeminicus Rottb, macro-elements, heavy metals

\section{INTRODUCTION}

Sewage water has impacts on the environment because it may contain high concentrations of heavy metals (Al-Musharafi, 2013). Naturally growing grazing plant species like Zygophyllum album L. Suaeda aegyptiaca and Cyprus rotundus that grow along the Red Sea Coast may accumulate heavy metals in their tissues due to the sewage water of Jeddah City discharged into the Seawater.
Growth of plant species under sewage water may contain high concentrations of heavy metals like $\mathrm{Fe}, \mathrm{Cu}, \mathrm{Zn}, \mathrm{Ni}, \mathrm{Cd}, \mathrm{Mn}, \mathrm{Pb}$, Co (Webber, 1972). Some plant species growing along the Red Sea Coast accumulate heavy metals like $\mathrm{CU}, \mathrm{Zn}, \mathrm{Mn}$, $\mathrm{Mo}, \mathrm{B}, \mathrm{Ag}, \mathrm{Al}, \mathrm{As}, \mathrm{Ba}, \mathrm{Co}, \mathrm{Cr}, \mathrm{Hg}, \mathrm{Pb}, \mathrm{Ni}$, Se (AlWehaibi, 2007), and the function of some of these elements is known as that of $\mathrm{Cu}, \mathrm{Zn}, \mathrm{Mn}, \mathrm{Me}$ and 
Bo, and others nobody knows their function and these always create big problems, (Alkorta et al. 2004). Plant species that can accumulate elements in their tissues at high concentrations are called phytoremediaters, and they help get rid of heavy metals that pollute soil and water (Lasat, 2002; Whiting et al. 2002; Hambidge, 2000). Plants absorb metals from polluted water and soil in different ways as suggested by (Prasad, 2004; Flathman and Lanza, 1998) and this will lead to removal or reservation or analysis of the different contaminants. Elements and heavy metals are absorbed by plans in the process of phytoremediation by different methods and ways as suggested by (Flathman and Lanza, 1998): phytodegradation, phytostimulation, phytovolatization, phytoextraction, rhizofiltration, phytostabilization. Plant species vary in their ability to accumulate heavy metals in their parts, (Khairia, 2012) found that seven plant species, Calotropus procera, Citrullus colocynthis, Rhazya stricta, Cassia italika, Phragmite australis, Cyprus laevigatus, and Argemone maxicana in the Reiyad area in Saudi Arabia accumulated the heavy metals $\mathrm{Fe}, \mathrm{Zn}, \mathrm{Cu}, \mathrm{Cr}, \mathrm{Ni}, \mathrm{Co}, \mathrm{Pb}, \mathrm{Cd}$, and the highest accumulation was in the roots, seconded by the stem, and then the leaves with the lowest concentrations, except $\mathrm{Cd}$ which nearly accumulated equally in the root, stem, and leaves, and the two species Phragmite australis, Cyprus laevigatus were the highest heavy metal accumulators compared to the other species. Panicum turgidum growing along the Arabian Gulf
Coast accumulated a high concentration of heavy metals particularly in its leaves and roots (El-Sheikh et al., 2012). Al-Sodany et al. (2012) found that concentration of the heavy metals in the forage plant Phragmite australis growing along Elberla Lake in Egypt was very high in the root than in the stem and then in the leaves, and also they found a significant relation between heavy metal concentration in the plant parts and their concentration in the lake water. This study aims to assess the effect of Jeddah City sewage water discharged in the Red Sea on the accumulation of heavy and toxic metals in three plant species Zygophyllum album L. Suaeda aegyptiaca and Cyprus rotundus and to compare the concentration of these metals in the same species growing in unpolluted site $30 \mathrm{~km}$ away.

\section{MATERIALS AND METHODS Jeddah sewage water:}

In 2005 the Ministry of Water and Electricity (200\%) estimated that the sewage water discharge from Jeddah City into the Red Sea water may reach up to $1149200 \mathrm{~m}^{3} /$ day in 2019 . The discharged sewage water is treated and untreated, and it contains both municipal and industrial wastes which contain heavy and toxic metals. Table (1) illustrates the results of the heavy and toxic metals analyzed in the normal water, and treated and untreated sewage water. Most of these metals are present in high concentrations in untreated and secondary treated sewage water, while the metals $\mathrm{Mo}, \mathrm{Cd}, \mathrm{Ag}, \mathrm{Al}, \mathrm{Co}$, and Se are present in very low concentrations in all types of water.

Table (1): Heavy metals (mg/L) in normal water, treated and untreated sewage water

\begin{tabular}{|l|l|l|l|l|l|l|l|l|l|l|l|l|l|l|l|l|}
\hline element & $\mathrm{Zn}$ & $\mathrm{Cu}$ & $\mathrm{Mn}$ & $\mathrm{B}$ & $\mathrm{Mo}$ & $\mathrm{Cr}$ & $\mathrm{Ni}$ & $\mathrm{Pb}$ & $\mathrm{As}$ & $\mathrm{Ba}$ & $\mathrm{Hg}$ & $\mathrm{Cd}$ & $\mathrm{Ag}$ & $\mathrm{Al}$ & $\mathrm{Co}$ & $\mathrm{Se}$ \\
\hline $\begin{array}{l}\text { Normal } \\
\text { water }\end{array}$ & 3.3 & 2.8 & 0.9 & 4.8 & $\leq 0.1$ & 1.6 & 4.1 & 0.5 & 0.13 & 10 & $\leq 0.1$ & $\leq 0.1$ & $\leq 0.1$ & $\leq 0.1$ & $\leq 0.1$ & $\leq 0.1$ \\
\hline $\begin{array}{l}\text { Treated } \\
\text { water }\end{array}$ & 0.2 & 0.3 & 0.1 & 219 & $\leq 0.1$ & 0.3 & $\leq 0.1$ & 0.1 & 0.1 & $\leq 0.1$ & $\leq 0.1$ & $\leq 0.1$ & $\leq 0.1$ & $\leq 0.1$ & $\leq 0.1$ & $\leq 0.1$ \\
\hline $\begin{array}{l}\text { Untreated } \\
\text { water }\end{array}$ & 25.8 & 5.6 & 60.2 & 1296 & $\leq 0.1$ & 20.5 & 10.2 & 0.6 & 6.6 & 23.7 & $\leq 0.1$ & $\leq 0.1$ & $\leq 0.1$ & $\leq 0.1$ & $\leq 0.1$ & $\leq 0.1$ \\
\hline
\end{tabular}

This sewage water discharging may have harmful effects on the grazing plant communities growing along the Red Sea Coast thus accumulating toxic metals that enter bodies of the animals grazing on them and consequently enter the human bodies who feed on these animals.

\section{Locations:}


Two locations were chosen to run this study, the first is the polluted area along the Red Sea Coast south Jeddah Province and it represents the area near the sewage water discharge. The other location is $30 \mathrm{~km}$ away from the polluted site and it represents the control. Three naturally growing plant species ( Zygophyllum album, Suaeda aegyptiaca, and Cyprus rotundus ) were selected for analysis of their contents of heavy metals.

\section{Samples collection:}

Fresh plant samples from leaves, stems, and roots were collected from the species Zygophyllum album, Suaeda aegyptiaca, while for Cyprus rotundus only the shoot and root systems were prepared. The samples were placed in plastic bags, then cleaned from debris and dust by brushing, and roots were immersed in distilled water for washing from dust. The plant samples were then dried for 48 hours in an oven at $75^{\circ} \mathrm{C}$ and crushed into a fine powder and put into glass containers tidily closed.

\section{Digestion of the samples:}

The plant samples were digested using Hamphries, (1956) method. A weight of $0.1 \mathrm{gm}$ of the plant sample was placed into digestion tube, then $1 \mathrm{ml}$ of concentrated sulphuric acid $\left(\mathrm{H}_{2} \mathrm{SO}_{4}\right)$ was added, and the tube was placed in a sand bath at low temperature, then the temperature was raised gradually till the sample changed into a black homogenous fluid. Then the tubes were cooled and $1 \mathrm{ml}$ of concentrated $\mathrm{H}_{2} \mathrm{SO}_{4}$ and perchloric acid were added (1:1 by volume). Heating of the samples in the tubes was repeated till white fumes appeared and the color of the mixture changed into a colorless watery solution. The content of the digestion tube was poured into a cylinder and distilled water added up to $50 \mathrm{ml}$. Heavy metals were analyzed from these prepared samples.

\section{Analysis of the heavy metals:}

Heavy metals were analyzed in the plants and water samples using the instrument Inductively Coupled Plasma, Optical Emission Spectrometer, Model Optima 4100 DV, Perkin.

\section{Percentage of heavy metals of accumulation in plant tissues:}

The concentration of the heavy metal in the shoot system was divided by its concentration in the root system to know whether the plant species is hyperaccumulator or not.

\section{Percentage of metals in plant species in polluted aria related to unpolluted aria:}

The concentration of the heavy metal in the plant species growing in the polluted area was divided by its concentration in those growing in the unpolluted area.

\section{Statistical Analysis:}

From each sample, three replications were taken and results were analyzed for averages and standard deviation (LSD) and significant differences at (5\%) using the one-way analysis of variance, using the SPSS program.

\section{RESULTS}

\section{Heavy metal accumulation in Zygophyllum album:}

The results in table (2) show that Al was the highest metal accumulated in Zygophyllum album in location 1 near the sewage water discharge area with a concentration of $3166 \mathrm{mg} / \mathrm{L}$ while its concentration in location 2 (unpolluted) is 85.2 $\mathrm{mg} / \mathrm{L}$. Seconded by Fe with $2831 \mathrm{mg} / \mathrm{L}$ in location 1 and $555 \mathrm{mg} / \mathrm{L}$ in location 2 (unpolluted), then $\mathrm{Zn}$ with concentration of $416.2 \mathrm{mg} / \mathrm{L}$ in location 1 (polluted) and $39.5 \mathrm{mg} / \mathrm{L}$ in location 2 (unpolluted), then $\mathrm{Mn}$ with concentration of $156.2 \mathrm{mg} / \mathrm{L}$ in location 1 (polluted) and $64 \mathrm{mg} / \mathrm{L}$ in location 2 (unpolluted), then $\mathrm{Pb}$ with $43.2 \mathrm{mg} / \mathrm{L}$ in location 1 and $0.00 \mathrm{mg} / \mathrm{L}$ in location 2 , then comes $\mathrm{Cu}$ with 42.7 and 23.9, and Mo metal with 37 and 11.46 , then Ba with 27.5 and $3.8 \mathrm{mg} / \mathrm{L}$, then $\mathrm{Cr}$ with 19.2 and 4.5 then $\mathrm{Ni}$ with 17.13 and 4.25 , Co with 1.54 and $0.13 \mathrm{mg} / \mathrm{L}$, then $B$ with 0.04 and $0.03 \mathrm{mg} / \mathrm{L}$ in location 1 (polluted) and location 2 (unpolluted) respectively. Zygophyllum album accumulated in its leaves the heavy metals $\mathrm{Al}, \mathrm{Fe}, \mathrm{Zn}, \mathrm{Cu}, \mathrm{Mn}, \mathrm{Cr}$, $\mathrm{Ni}, \mathrm{Cd}, \mathrm{B}, \mathrm{Ba}, \mathrm{Ag}$ at the highest concentration levels compared with those accumulated in the root and stem. And the species accumulated in its stem the heavy metals $\mathrm{Mo}$ and $\mathrm{Pb}$ at the highest level compared to those accumulated in its leaves and root, and the root accumulated the least accumulation of the metals. The following heavy metals $\mathrm{Fe}, \mathrm{Zn}, \mathrm{Mn}, \mathrm{Mo}$. $\mathrm{Ni}, \mathrm{Ba}, \mathrm{Ag}, \mathrm{Pb}, \mathrm{Cd}$ accumulated in the plant stem at a higher level than their accumulation in the plant root. 
Table (2): Concentration of heavy metals in plan parts of Zygophyllum album

\begin{tabular}{|c|c|c|c|c|}
\hline Elements & Soil & Leaves & Stems & Roots \\
\hline \multirow{3}{*}{$\mathrm{Fe}$} & Polluted & $1493 \pm 13$ & $736 \pm 8$ & $602 \pm 12$ \\
\hline & Unpolluted & $328 \pm 3$ & $115 \pm 10$ & $112 \pm 23$ \\
\hline & Significance & $0.001 * *$ & $0.005^{* *}$ & $0.031 * *$ \\
\hline \multirow{3}{*}{$\mathrm{Zn}$} & Polluted & $231 \pm 0,04$ & $104 \pm 0,01$ & $83.2 \pm 0,01$ \\
\hline & Unpolluted & $24.3 \pm 0,04$ & $9.6 \pm 0,01$ & $5.6 \pm 0,05$ \\
\hline & Significance & $0.001 * *$ & $0.001 * *$ & $0.001 * *$ \\
\hline \multirow{3}{*}{$\mathrm{Cu}$} & Polluted & $22.3 \pm 0,09$ & $14.3 \pm 0,002$ & $17.6 \pm 0,002$ \\
\hline & Unpolluted & $2.2 \pm 0,0003$ & $1.3 \pm 0,0003$ & $4.2 \pm 0,0003$ \\
\hline & Significance & $0.001^{* *}$ & $0.002 * *$ & $0.006 * *$ \\
\hline \multirow{3}{*}{$\mathrm{Mn}$} & Polluted & $88.4 \pm 0,008$ & $43.7 \pm 0,003$ & $24.1 \pm 0,002$ \\
\hline & Unpolluted & $38.7 \pm 0,002$ & $13.1 \pm 0,001$ & $12.2 \pm 0,002$ \\
\hline & Significance & $0.004^{* *}$ & $0.013^{*}$ & $0.022 *$ \\
\hline \multirow{3}{*}{ B } & Polluted & $0.02 \pm 0,002$ & $0.01 \pm 0,002$ & $0.01 \pm 0,002$ \\
\hline & Unpolluted & $0.01 \pm 0,002$ & $0.01 \pm 0,002$ & $0.01 \pm 0,002$ \\
\hline & Significance & & & \\
\hline \multirow[t]{3}{*}{ Mo } & Polluted & $11.7 \pm 0,02$ & $30.8 \pm 0,01$ & $0.5 \pm 0,001$ \\
\hline & Unpolluted & $6.67 \pm 0,007$ & $0.55 \pm 0,001$ & $0.33 \pm 0,003$ \\
\hline & Significance & $0.017^{*}$ & $0.001 * *$ & $0.460 *$ \\
\hline \multirow{3}{*}{$\mathrm{Cr}$} & Polluted & $9.2 \pm 0,001$ & $4.6 \pm 0,001$ & $5.4 \pm 0,0002$ \\
\hline & Unpolluted & $1.6 \pm 0,0003$ & $1.4 \pm 0,004$ & $1.5 \pm 0,0003$ \\
\hline & Significance & $0.005^{* *}$ & $0.001 * *$ & $0.006 * *$ \\
\hline \multirow{3}{*}{$\mathrm{Ni}$} & Polluted & $9.4 \pm 0,001$ & $4.2 \pm 0,004$ & $3.53 \pm 0,01$ \\
\hline & Unpolluted & $1.28 \pm 0,004$ & $1.15 \pm 0,003$ & $1.82 \pm 0,001$ \\
\hline & Significance & $0.001 * *$ & $0.012 * *$ & $0.040 * *$ \\
\hline \multirow[t]{3}{*}{$\mathrm{Ba}$} & Polluted & $21.7 \pm 0,003$ & $3.5 \pm 0,006$ & $2.3 \pm 0,006$ \\
\hline & Unpolluted & $1.8 \pm 0,0001$ & $1.5 \pm 0,003$ & $0.5 \pm 0,0004$ \\
\hline & Significance & $0.005^{* *}$ & $0.036^{*}$ & $0.001 * *$ \\
\hline \multirow{3}{*}{ Al } & Polluted & $1472 \pm 0,01$ & $723 \pm 0,01$ & $991 \pm 0,012$ \\
\hline & Unpolluted & $28.5 \pm 0,3$ & $22.4 \pm 0,04$ & $34.3 \pm 0,01$ \\
\hline & Significance & $0.009 * *$ & $0.005 * *$ & ${ }^{\circ \circ} 0,002$ \\
\hline \multirow{3}{*}{$\mathrm{Ag}$} & Polluted & $3.22 \pm 0,001$ & $1.07 \pm 0,001$ & $0.47 \pm 0,001$ \\
\hline & Unpolluted & $0.12 \pm 0,002$ & $0.01 \pm 0,001$ & $0.35 \pm 0,004$ \\
\hline & Significance & $0.007 * *$ & $0.005 * *$ & $0.036 * *$ \\
\hline \multirow[t]{3}{*}{ Co } & Polluted & 0,97 & 0,12 & 0,45 \\
\hline & Unpolluted & 0,08 & 0,02 & 0,03 \\
\hline & Significance & $0.001 * *$ & $0.002 * *$ & $0.002 * *$ \\
\hline $\mathrm{Pb}$ & Polluted & $8.9 \pm 0,002$ & $19.4 \pm 0,001$ & $14.9 \pm 0,02$ \\
\hline $\mathrm{Cd}$ & Polluted & $0.23 \pm 0,001$ & $0.08 \pm 00,001$ & $0.02 \pm 0,001$ \\
\hline
\end{tabular}




\section{Heavy metal accumulation in Suaeda aegyptiaca :}

The results in a table (3) show that Al was the highest metal accumulated in Suaeda aegyptiaca in location 1 near the sewage water discharge area with a concentration of $3141 \mathrm{mg} / \mathrm{L}$ while its concentration in location 2 (unpolluted) is 227.4 $\mathrm{mg} / \mathrm{L}$. Seconded by Fe with $2092 \mathrm{mg} / \mathrm{L}$ in location 1 and $871 \mathrm{mg} / \mathrm{L}$ in location 2 (unpolluted), then $\mathrm{Mn}$ with concentration of $218.8 \mathrm{mg} / \mathrm{L}$ in location 1 (polluted) and $90.9 \mathrm{mg} / \mathrm{L}$ in location 2 (unpolluted), then $\mathrm{Zn}$ with concentration of $147.3 \mathrm{mg} / \mathrm{L}$ in location 1 (polluted) and $36.3 \mathrm{mg} / \mathrm{L}$ in location 2 (unpolluted), then $\mathrm{Cu}$ with $42.7 \mathrm{mg} / \mathrm{L}$ in location 1 and $23.9 \mathrm{mg} / \mathrm{L}$ in location 2 , then comes Mo with 39.4 and 0.14 , and $\mathrm{Pb}$ metal with 34.8 and 0.00 , then Ni with 16.8 and $5.29 \mathrm{mg} / \mathrm{L}$, then Cr with 12.5 and 3.9 then Ba with 8.7 and 1.9, Ag with 4.76 and $0.48 \mathrm{mg} / \mathrm{L}$, then Co with 0.75 and 0.1 , then $B$ with 0.04 and $0.03 \mathrm{mg} / \mathrm{L}$ in location 1 (polluted) and location 2 (unpolluted) respectively. Suaeda aegyptiaca accumulated in its leaves the heavy metals $\mathrm{Al}, \mathrm{Fe}, \mathrm{Zn}, \mathrm{B}, \mathrm{Ba}, \mathrm{Pb}$ at the highest concentration levels compared with those accumulated in the root and stem. And the species accumulated in its root the heavy metals $\mathrm{Cu}, \mathrm{Mn}$, and $\mathrm{Cr}$ at the highest level compared to those accumulated in its leaves and stem, and the stem witnessed the highest accumulation of the metal Mo. The metal $\mathrm{Ni}$ was equally accumulated in the leaves and root. The plant stem was generally with the lowest metal accumulation compared to the plant leaves and root.

Table (3): Concentration of heavy metals in plan parts of Suaeda aegyptiaca

\begin{tabular}{|c|c|c|c|c|}
\hline Element & Soil & Leaves & Stem & Roots \\
\hline \multirow[t]{3}{*}{$\mathrm{Fe}$} & $\begin{array}{l}\text { Location } 1 \\
\text { (polluted) }\end{array}$ & $831 \pm 19$ & $688 \pm 10$ & $573 \pm 6$ \\
\hline & $\begin{array}{r}\text { Ulocation } \\
\text { (unpolluted) }\end{array}$ & $322 \pm 15$ & $307 \pm 3$ & $242 \pm 6$ \\
\hline & significance & $0.003^{* *}$ & $0.007^{* *}$ & $0.003 * *$ \\
\hline \multirow{3}{*}{$\mathrm{Zn}$} & Location 1 & $78.1 \pm 0,01$ & $36.7 \pm 30,01$ & $32.5 \pm 0,01$ \\
\hline & Location 2 & $21.1 \pm 0,01$ & $10.1 \pm 0,05$ & $5.1 \pm 0,01$ \\
\hline & significance & $0.021 *$ & $0.015^{*}$ & $0.001 * *$ \\
\hline \multirow{3}{*}{$\mathrm{Cu}$} & Location 1 & $16.2 \pm 0,02$ & $9.1 \pm 0,004$ & $17.3 \pm 0,001$ \\
\hline & Location 2 & $8.3 \pm 0,004$ & $6.4 \pm 0,003$ & $9.2 \pm 0,001$ \\
\hline & significance & $0.004^{* *}$ & 0,613 & $0.011^{* *}$ \\
\hline \multirow{3}{*}{$\mathrm{Mn}$} & Location 1 & $73.1 \pm 0,003$ & $51.1 \pm 0,002$ & $94.4 \pm 0,012$ \\
\hline & Location 2 & $0,0316.4 \pm$ & $23.6 \pm 0,002$ & $0,005 \pm 50,9$ \\
\hline & significance & $0.001^{* *}$ & $0.018^{*}$ & $0.019 *$ \\
\hline \multirow{3}{*}{ B } & Location 1 & $0.02 \pm 0,002$ & $0.01 \pm 0,002$ & $0.01 \pm 0,002$ \\
\hline & Location 2 & $0.01 \pm 0,002$ & $0.01 \pm 0,002$ & $0.01 \pm 0,002$ \\
\hline & significance & $0.012^{*}$ & & \\
\hline \multirow[t]{3}{*}{ Mo } & Location 1 & $8.1 \pm 0,02$ & $30.8 \pm 0,01$ & $0.5 \pm 0,001$ \\
\hline & Location 2 & $0,001 \pm 0,51$ & $0,001 \pm 0,55$ & $0.33 \pm 0,003$ \\
\hline & significance & $0.001^{* *}$ & $0.001^{* *}$ & 0.460 \\
\hline \multirow{3}{*}{$\mathrm{Cr}$} & Location 1 & $4.5 \pm 0,005$ & $2.4 \pm 0,001$ & $5.6 \pm 0,001$ \\
\hline & Location 2 & $1.4 \pm 0,005$ & $1.4 \pm 0,005$ & $1.1 \pm 0,002$ \\
\hline & significance & $0.026^{*}$ & $0.054^{*}$ & $0.006^{*}$ \\
\hline \multirow{3}{*}{$\mathrm{Ni}$} & Location 1 & $5.71 \pm 0,004$ & $4.67 \pm 0,002$ & $5.7 \pm 0,001$ \\
\hline & Location 2 & $1.87 \pm 0,002$ & $1.4 \pm 0,003$ & $1.95 \pm 0,002$ \\
\hline & significance & $0.019^{*}$ & $0.031^{*}$ & $0.039^{*}$ \\
\hline \multirow{3}{*}{$\mathrm{Ba}$} & Location 1 & $5.3 \pm 0,001$ & $2.2 \pm 0,0002$ & $1.2 \pm 0,002$ \\
\hline & Location 2 & $1.7 \pm 0,0002$ & $0.1 \pm 0,0001$ & $0,001 \pm 0,1$ \\
\hline & significance & $0.013^{* *}$ & $0.008^{* *}$ & $0.01^{* *}$ \\
\hline \multirow{3}{*}{ Al } & Location 1 & $2022 \pm 0,1$ & $586 \pm 0,1$ & $0,07 \pm 533$ \\
\hline & Location 2 & $137.3 \pm 0,1$ & $57.5 \pm 0,1$ & $32.6 \pm 1,2$ \\
\hline & significance & $0.004^{* *}$ & $0.012 * *$ & $0.003 * *$ \\
\hline $\mathrm{Pb}$ & Location 1 & 16.3 & 5.7 & 12.8 \\
\hline
\end{tabular}

\section{Heavy metal accumulation in Cyprus rotundus:}

The results in Cyprus rotundus table (4) show that Al was the highest metal accumulated in location 1 near the sewage water discharge area with a concentration of $3245 \mathrm{mg} / \mathrm{L}$ while its concentration in location 2 (unpolluted) is 197.7 $\mathrm{mg} / \mathrm{L}$. Seconded by Fe with $3868 \mathrm{mg} / \mathrm{L}$ in location 1 and $1988 \mathrm{mg} / \mathrm{L}$ in location 2 (unpolluted), then $\mathrm{Zn}$ with concentration of $258 \mathrm{mg} / \mathrm{L}$ in location 1 (polluted) and $67.3 \mathrm{mg} / \mathrm{L}$ in location 2 (unpolluted), then $\mathrm{Mn}$ with concentration of $156 \mathrm{mg} / \mathrm{L}$ in location 
1 (polluted) and $82.3 \mathrm{mg} / \mathrm{L}$ in location 2 (unpolluted), then Ba with $45.4 \mathrm{mg} / \mathrm{L}$ in location 1 and $3.9 \mathrm{mg} / \mathrm{L}$ in location 2 , then comes $\mathrm{Cu}$ with 43.4 and 18.1, and $\mathrm{Pb}$ metal with 37.6 and 0.00 , then $\mathrm{Cr}$ with 19.7 and $3.3 \mathrm{mg} / \mathrm{L}$, then Ni with 17.07 and 2.86 then Mo with 10.43 and 7.06, Co with 1.85 and $0.18 \mathrm{mg} / \mathrm{L}$, then $\mathrm{Ag}$ with 1.64 and 0.03 , then $\mathrm{B}$ with 0.04 and $0.03 \mathrm{mg} / \mathrm{L}$ in location 1 (polluted) and location 2 (unpolluted) respectively. Cyprus rotundus accumulated in its shoot system 8 heavy

Table (4): Concentration of heavy metals in plan parts of Cyprus rotundus

\begin{tabular}{|c|c|c|c|}
\hline Elements & Soil & Shoot system & Root system \\
\hline \multirow{3}{*}{$\mathrm{Fe}$} & Polluted & $2211 \pm 62$ & $3657 \pm 16$ \\
\hline & Unpolluted & $990 \pm 8$ & $998 \pm 2$ \\
\hline & Significance & $0.003 * *$ & $0.001^{* *}$ \\
\hline \multirow{3}{*}{$\mathrm{Zn}$} & Polluted & $152 \pm 0,01$ & $106 \pm 0.01$ \\
\hline & Unpolluted & $38.8 \pm 0,02$ & $8.5 \pm 0,02$ \\
\hline & Significance & $0.001 * *$ & $0.001 * *$ \\
\hline \multirow{3}{*}{$\mathrm{Cu}$} & Polluted & $18.5 \pm 0,002$ & $24.9 \pm 0,002$ \\
\hline & Unpolluted & $5.5 \pm 0,001$ & $12.6 \pm 0,001$ \\
\hline & Significance & $0.002 * *$ & $0.005^{* *}$ \\
\hline \multirow{3}{*}{$\mathrm{Mn}$} & Polluted & $86.9 \pm 0,03$ & $69.1 \pm 0,008$ \\
\hline & Unpolluted & $48.9 \pm 0,01$ & $33.4 \pm 0,0003$ \\
\hline & Significance & $0.020 *$ & $0.020 *$ \\
\hline \multirow{3}{*}{ B } & Polluted & $0.03 \pm 0,002$ & $0.01 \pm 0,002$ \\
\hline & Unpolluted & $0.02 \pm 0,002$ & $0.01 \pm 0,002$ \\
\hline & Significance & & \\
\hline \multirow[t]{3}{*}{ Mo } & Polluted & $7.2 \pm 0,02$ & $3.23 \pm 0,15$ \\
\hline & Unpolluted & $4.89 \pm 0,01$ & $2.17 \pm 0,01$ \\
\hline & Significance & 0,061 & 0,089 \\
\hline \multirow{3}{*}{$\mathrm{Cr}$} & Polluted & $3.5 \pm 0,001$ & $16.2 \pm 0,001$ \\
\hline & Unpolluted & $1.6 \pm 0,0003$ & $1.8 \pm 0,004$ \\
\hline & Significance & 0,061 & $0.003 * *$ \\
\hline \multirow{3}{*}{$\mathrm{Ni}$} & Polluted & $7.97 \pm 0,001$ & $9.1 \pm 0,004$ \\
\hline & Unpolluted & $1.33 \pm 0,004$ & $1.53 \pm 0,003$ \\
\hline & Significance & $0.009 * *$ & $0.005^{* *}$ \\
\hline \multirow[t]{3}{*}{$\mathrm{Ba}$} & Polluted & $19.3 \pm 0,003$ & $26.1 \pm 0,006$ \\
\hline & Unpolluted & $1.8 \pm 0,0001$ & $2.2 \pm 0,003$ \\
\hline & Significance & $0.007 * *$ & $0.002 * *$ \\
\hline \multirow{3}{*}{$\mathrm{Al}$} & Polluted & $923 \pm 0,1$ & $2322 \pm 0,1$ \\
\hline & Unpolluted & $82.6 \pm 0,3$ & $114.1 \pm 0,04$ \\
\hline & Significance & $0.008 * *$ & $0.006 * *$ \\
\hline \multirow{3}{*}{$\mathrm{Ag}$} & Polluted & $1.17 \pm 0,001$ & $0.47 \pm 0,001$ \\
\hline & Unpolluted & $0.12 \pm 0,002$ & $0.18 \pm 0,001$ \\
\hline & Significance & $0.002 * *$ & $1.58 *$ \\
\hline \multirow[t]{3}{*}{ Co } & Polluted & 0,27 & 0,13 \\
\hline & Unpolluted & 0,05 & 0,02 \\
\hline & Significance & $0.001 * *$ & $0.021 *$ \\
\hline $\mathrm{Pb}$ & Polluted & $9.2 \pm 0,002$ & $28.4 \pm 0,001$ \\
\hline $\mathrm{Cd}$ & Polluted & $1.23 \pm 0.001$ & $1.08 \pm 0,001$ \\
\hline \multirow[t]{3}{*}{$\mathrm{Se}$} & Polluted & 6.4 & 8.1 \\
\hline & Unpolluted & 0.23 & 0.63 \\
\hline & Significance & $0.001 * *$ & $0.001^{* *}$ \\
\hline
\end{tabular}

metals $\mathrm{Al}, \mathrm{Zn}, \mathrm{Mn}, \mathrm{B}, \mathrm{Mo}, \mathrm{Ag}, \mathrm{Co}, \mathrm{Cd}$, at the highest concentration levels compared with those accumulated in the root system. And the species accumulated in its root system 7 of the heavy metals $\mathrm{Fe}, \mathrm{Cu}, \mathrm{Cr}, \mathrm{Ni}, \mathrm{Ba}, \mathrm{Pb}$, Se, at the highest level compared to those accumulated in its shoot system. 


\section{Biological Absorption Factor:}

It is the division of the concentration of the metal in the shoot system by its concentration in the root system to see whether the plant species is a metal accumulator or not. The results in a table (5) illustrate that Zygophyllum album growing in polluted soil with sewage water accumulated 14 heavy metals, $\mathrm{Fe}, \mathrm{Al}, \mathrm{Zn}, \mathrm{Cu}$, $\mathrm{Mn}, \mathrm{Ni}, \mathrm{Cr}, \mathrm{Ba}, \mathrm{Mo}, \mathrm{Pb}, \mathrm{B}, \mathrm{Co}, \mathrm{Ag}$, and $\mathrm{Cd}$ in its shoot system at higher concentrations than their concentration in its root system, and the plant species Suaeda aegyptiaca accumulated 11 heavy metals, $\mathrm{Fe}, \mathrm{Al}, \mathrm{Zn}, \mathrm{Cu}, \mathrm{Mn}$, $\mathrm{Ni}, \mathrm{Cr}, \mathrm{Ba}, \mathrm{Mo}, \mathrm{Pb}, \mathrm{B}$, while the plant species Cyprus rotundus accumulated 7 heavy metals from polluted soil with sewage water, $\mathrm{Zn}, \mathrm{Mn}, \mathrm{Mo}, \mathrm{B}, \mathrm{Ag}, \mathrm{Cd}$, As at higher concentrations than their roots.

Table (5): The Biological Absorption Factor of the plant species:

\begin{tabular}{|c|c|c|c|c|c|c|c|c|c|c|c|c|c|c|c|c|}
\hline \multicolumn{17}{|c|}{ Accumulation (\%) } \\
\hline & $\mathrm{Fe}$ & Al & $\mathrm{Zn}$ & $\mathrm{Cu}$ & $\mathrm{Mn}$ & $\mathrm{Ni}$ & $\mathrm{Cr}$ & $\mathrm{Ba}$ & Mo & $\mathbf{P b}$ & B & Co & $\mathbf{A g}$ & $\mathrm{Cd}$ & As & $\mathrm{Se}$ \\
\hline $\begin{array}{l}\text { Zygophyllum } \\
\text { album }\end{array}$ & 3.7 & 2.2 & 4 & 2.1 & 5.5 & 3.9 & 2.6 & 10.9 & 1.14 & 1.9 & 3 & 2.4 & 9.1 & 1.5 & -- & -- \\
\hline $\begin{array}{r}\text { Suaeda } \\
\text { aegyptiaca }\end{array}$ & 2.8 & 5 & 3.5 & 1.5 & 1.3 & 1.8 & 1.2 & 6.3 & 78 & 1.8 & 3 & -- & -- & --- & -- & -- \\
\hline $\begin{array}{l}\text { Cyperus } \\
\text { rotundus }\end{array}$ & 0.6 & 0.2 & 1.6 & 0.7 & 1.3 & 0.9 & 0.2 & 0.7 & 2.2 & 0.32 & 3 & 0.2 & 2.5 & 1.1 & 1.07 & 0.78 \\
\hline
\end{tabular}

\section{Which of the three plant species is a hyper accumulator:}

The percentages of accumulation of heavy metals by the plant species growing in the sewage water polluted site were divided by the accumulation values by these species in the unpolluted location 2 . The results are presented in table (6). The results indicated that concentrations of all studied heavy metals in all parts of the studied plant species are higher than the concentrations of these metals in the same plant species growing in the unpolluted location. Aluminum is very highly accumulated in the shoot system compared to its concentration in the root system of the species, particularly in the Zygophyllum album.

Table (6): Percentages of accumulated heavy metals in polluted site to values accumulated in the unpolluted site:

\begin{tabular}{|c|l|l|l|l|l|l|l|l|l|l|l|l|}
\hline \multicolumn{1}{|c|}{ Accumulation (\%) } & $\mathrm{Fe}$ & $\mathrm{Al}$ & $\mathrm{Zn}$ & $\mathrm{Cu}$ & $\mathrm{Mn}$ & $\mathrm{Ni}$ & $\mathrm{Cr}$ & $\mathrm{Ba}$ & $\mathrm{Mo}$ & $\mathrm{B}$ & $\mathrm{Co}$ & $\mathrm{Ag}$ \\
\hline $\begin{array}{c}\text { Zygophyllum } \\
\text { album }\end{array}$ & 4.8 & 37.2 & 10.5 & 7.03 & 2.4 & 4.03 & 4.3 & 7.2 & 3.2 & 1.3 & 11.8 & - \\
\hline $\begin{array}{c}\text { Suaeda } \\
\text { aegyptiaca }\end{array}$ & 2.5 & 13.8 & 4.05 & 1.7 & 2.4 & 3.03 & 3.2 & 4.5 & 2.8 & 1.3 & 7.5 & 9.9 \\
\hline $\begin{array}{c}\text { Cyperus } \\
\text { rotundus }\end{array}$ & 2.9 & 16.3 & 3.8 & 2.4 & 1.9 & 5.2 & 8 & 11.6 & 1.4 & 1.3 & 10.2 & 5.5 \\
\hline
\end{tabular}

\section{DISCUSSION}

Jeddah City sewage water (municipal and industrial) is discharged into the Red Sea water south of the city. This study was undertaken to assess the impact of this polluted sewage effluent on the habitat of this region especially on plant species growing in this area. Three plant species of those growing naturally in this area were chosen for this study, to determine the heavy and toxic metals accumulated in their tissues, and to compare it with the concentrations of these metals accumulated in the tissues of the same plant species growing naturally in a different habitat 
located $30 \mathrm{~km}$ away from this polluted site, to see whether planting of such plant species can eliminate and alleviate toxic heavy metals from contaminated soils with the sewage water. The results indicated variation between the three plant species in their capability of accumulating heavy metals in their tissues, and variation between the different plant parts (leaves, stem, root) in the magnitude of the heavy metal concentrations they can accumulate and the type of the heavy metal they can select. Also, the metals varied in their concentrations in the plant tissues. The species growing in the polluted site near the sewage water discharged area significantly accumulated high concentrations of heavy metals compared to those growing in the unpolluted area. This agrees with the findings of many researchers (Garcia et al., 2004) who found a significant increase in heavy metal concentration in tissues of the plant Piptatherum miliaceum (Smilo grass) under irrigation with sewage water compared to the concentration of these metals in the same species when irrigated with normal water. Al-Jaloud et al. (1995) and Al-Jaloud, (1994) irrigated field crops with sewage water and found a significant increase in heavy metal concentrations in their tissues compared to those irrigated with normal water. And (Baeshen, 2008) found high heavy metal concentrations in the desert plants growing east of Jeddah city in Saudi Arabia and irrigated with the sewage water. The three plant species differed in the quantities of heavy metals they accumulated in their tissues, and in the types of heavy metals, they accumulated in their different parts and the types of heavy metals selected by each plant species.

The heavy metals accumulated by Zygophyllum album are $\mathrm{Al}, \mathrm{Fe}, \mathrm{Zn}, \mathrm{Cu}, \mathrm{Mn}, \mathrm{Cr}, \mathrm{Ni}, \mathrm{Ba}, \mathrm{Cd}, \mathrm{Ag}, \mathrm{Co}$, and $\mathrm{Pb}$, and nearly all of them except $\mathrm{Mo}$ and $\mathrm{Pb}$ are accumulated in the leaves at higher levels compared to their concentrations in the stem and root, with the lowest concentrations of these metals in the plant root. The heavy metals accumulated by Suaeda aegyptiaca growing along the Red Sea Coastal polluted area near the sewage water discharge are $\mathrm{Al}, \mathrm{Fe}, \mathrm{Mn}, \mathrm{Zn}, \mathrm{Cu}, \mathrm{Mo}, \mathrm{Pb}, \mathrm{Ni}$, $\mathrm{Cr}, \mathrm{Ba}$, and 5 of them dominated in the leaves ( $\mathrm{Fe}$, $\mathrm{Zn}, \mathrm{Al}, \mathrm{Ba}, \mathrm{Pb})$, and 3 dominated in the root $(\mathrm{Cu}$, $\mathrm{Mn}, \mathrm{Cr}$ ) and only one dominated in the stem ( $\mathrm{Mo}$ ). The plant species Cyprus rotundus accumulated in its shoot system the metals Fe, Zn, Mn, B, Mo, $\mathrm{Ag}$, and $\mathrm{Cd}$ at higher concentrations than in its root system, and accumulated in its root system the metals $\mathrm{Cu}, \mathrm{Cr}, \mathrm{Ni}, \mathrm{Ba}, \mathrm{Al}, \mathrm{Pb}$, and $\mathrm{Se}$ at higher concentrations than in its shoot system.
Zygophyllum album can extract and accumulate 13 heavy metals, $\mathrm{Fe}, \mathrm{Al}, \mathrm{Zn}, \mathrm{Cu}, \mathrm{Mn}, \mathrm{Ni}, \mathrm{Cr}, \mathrm{Ba}, \mathrm{Mo}, \mathrm{Pb}$, $\mathrm{Co}, \mathrm{Ag}$, and $\mathrm{Cd}$ from polluted soil with sewage water, and the plant species Suaeda aegyptiaca can extract and accumulate 10 heavy metals, $\mathrm{Fe}, \mathrm{Al}$, $\mathrm{Zn}, \mathrm{Cu}, \mathrm{Mn}, \mathrm{Ni}, \mathrm{Cr}, \mathrm{Ba}, \mathrm{Mo}, \mathrm{Pb}$, while the plant species Cyprus rotundus can extract and accumulate 7 heavy metals from polluted soil with sewage water, $\mathrm{Zn}, \mathrm{Mn}, \mathrm{Mo}, \mathrm{B}, \mathrm{Ag}, \mathrm{Cd}$, As.

The three plant species growing in the location polluted with sewage water accumulated the 12 studied heavy metals ( $\mathrm{Fe}, \mathrm{Al}, \mathrm{Zn}, \mathrm{Cu}, \mathrm{Mn}, \mathrm{Ni}, \mathrm{Cr}, \mathrm{Ba}$, $\mathrm{Mo}, \mathrm{B}, \mathrm{Co}, \mathrm{Ag}$ ) in their different parts (leaves, stem, root) at higher concentrations than their accumulation undergrowth in the unpolluted location $30 \mathrm{~km}$ away from the polluted site. The plant species is considered an accumulator of heavy metals if the division of the shot content of a particular metal by its root content is more than one, and it is called unaccumulator if the result of this division is less than one, as was suggested by (McGraw et al. 2002; Zhao et al. 2000) who classified plant species into hyper-accumulators, accumulators and unaccumulators. According to these criteria, the Zygophyllum album is a higher accumulator than Suaeda aegyptiaca and Cyprus rotundus while Cyprus rotundus is the least plant accumulator of the three species accumulating only 7 metals. The reason why Cyprus rotundus is the least metal accumulator is that metals are accumulated in the root system at higher concentrations than in the shoot system because the species has intensive branching of rhizomes and tubers underground. The domination of plant roots to accumulate trace and heavy metals more than the shoot system is suggested by some researchers (Gupta et al.2008) found that roots of Pelargonium plants accumulated a significantly greater heavy metal concentration than aerial organs. Many other researchers reached the same results Khairia, 2012, determined heavy metals in seven plant species in the Reiyad area, Saudi Arabia and Al-Sodany et al. (2013) determined heavy metals in the species Phragmite australis in Egypt found the highest heavy metal accumulations were in the roots compared to shoot. Mazhoudi et al., (1997) found aerial parts of plants to accumulate low metal content compared with roots and hypothesized that roots could play an important role in metal retention by preventing an excessive and toxic accumulation in shoots.

Zygophyllum album is a higher extractor (accumulator) of the heavy metals $\mathrm{Al}, \mathrm{Zn}, \mathrm{Cu}, \mathrm{Mn}$, Mo, Co, compared to the other two species Suaeda 
aegyptiaca and Cyprus rotundus, and Cyprus rotundus is a higher accumulator than Zygophyllum album and Suaeda aegyptiaca for the metals $\mathrm{Cr}, \mathrm{Ni}$, $\mathrm{Ba}$, while Suaeda aegyptiaca is the higher accumulator for Ag. Aluminum was accumulated at the highest concentration level in the plant tissues compared to the other heavy metals and registered the highest concentration in Cyprus rotundus roots $(2322 \mathrm{mg} / \mathrm{L})$, and in the leaves of Suaeda aegypliaca it reached $(2022 \mathrm{mg} / \mathrm{L})$, while in the leaves of it Zygophyllum album reached 1472 mg/L, seconded by $\mathrm{Zn}$ then $\mathrm{Mn}$, and the concentration of all the other metals decreased in plant tissues. According to the suggestion of (Caille et al. 2005) that metal accumulators adopt three criteria relating to their ability to accumulate metals, summarized in the enhancement of absorption of the metal by the root, efficiency in transferring the metal from the root system to the shoot system, and tolerance of the plant to the high concentration of this toxic heavy metal. So based on these facts Zygophyllum album is considered a good heavy metals accumulator, then Suaeda aegypliaca while Cyprus rotundus is the least heavy metal accumulator of the three species.

\section{CONCLUSION}

It can be concluded that the three plant species Zygophyllum album, Suaeda aegypliaca, and Cyprus rotundus can be considered phytoremediators that can accumulate heavy and toxic metals in their tissues after absorbing them from contaminated soils and water. Zygophyllum album extracted and accumulated 13 heavy metals, $\mathrm{Fe}, \mathrm{Al}, \mathrm{Zn}, \mathrm{Cu}, \mathrm{Mn}, \mathrm{Ni}, \mathrm{Cr}, \mathrm{Ba}, \mathrm{Mo}, \mathrm{Pb}, \mathrm{Co}$, $\mathrm{Ag}$, and $\mathrm{Cd}$ from polluted soil with sewage water, and the plant species Suaeda aegyptiaca extracted and accumulated 10 heavy metals, $\mathrm{Fe}, \mathrm{Al}, \mathrm{Zn}, \mathrm{Cu}$, $\mathrm{Mn}, \mathrm{Ni}, \mathrm{Cr}, \mathrm{Ba}, \mathrm{Mo}, \mathrm{Pb}$, while the plant species Cyprus rotundus extracted and accumulated 7 heavy metals from polluted soil with sewage water, $\mathrm{Zn}, \mathrm{Mn}, \mathrm{Mo}, \mathrm{B}, \mathrm{Ag}, \mathrm{Cd}, \mathrm{As}$. The concentrations of heavy metals in the tissues of the tested plants are very high for the plants growing naturally near the site polluted with sewage water compared to the same species growing $30 \mathrm{~km}$ away in an unpolluted area. Heavy metals accumulated in different concentrations in the different plant parts (leaves, stem, root), and the species Cyprus rotundus because of its intensive branching underground rhizome and tubers the concentration of the heavy metals of most of the metals were in the root system compared to the shoot system. The three plant species Zygophyllum album, Suaeda aegyptiaca, and Cyprus rotundus can be used as phytoremediators for treatment of polluted soil and water from heavy toxic metals.

\section{REFERENCES}

Al- Jaloud, A. A., Hussain, G. Al- Saati, A. and Karimulluh, S. (1995). Effect of waste water on plant growth and soil properties. Arid soil Research and Rehabilition, 7: 173-179.

Al-Jaloud, A. A. (1994). Effect of irrigation with treated municipal waste water on soil and crops. JK AAU : Met. Env. Arid land Agric. Sci, 5:77-88.

Alkorta, I., Hernandez-Allica, J. , Becerril, J.M.; Amezaga, I., Albizu, I. and Garbisu, C. (2004). Recent findings on the phytoremediation of soils contaminated with environmentally toxic heavy metals and metalloids such as zinc, cadmium, lead, and arsenic. Environ. Sci. BioTechnol. 3: 71-90.

Al-Musharafi, S. K.; Mahmoud, I. Y. and Al-Bahry, S. N. (2013). Heavy Metal Pollution from Treated Sewage Effluent. Science Direct, Elsevier, vol. 5, pp. 344-348.

Al-Sodany, Y.M., El-Sheikh, M. A. and Shaltout, K. H. (2013) Elemente accumulation and nutritive value of Phragmites australis (Cav.) Trin. Ex Steudel in Lake Burullus: A Ramsar site, Egypt, Catrina, 8(1), 55-68.

Al-Wehaibi , M.A. (2007) . Accumulations of heavy metals in plants. Saudi J. of Biolo. Sci. ,14(2):73-96.

Baeshen, A. A. M. (2008). Evaluation the effect of sewage water accumulation on the vegetation formation east of Jeddah province. A thesis submitted to the Botany Department in partial fulfillment of the requirements for the Ph.D degree in Science. Girls College of Education Scientific Departments King Abdulaziz University Jeddah 1429200

Caille, N.; Vanlcon, C.; Leyva, I. C.; More, J. L. (2005). Metal transfer to plants grown in degraded sediment : use of radioactive isotope $203 \mathrm{Hg}$ and titanium . Sci. Total Environ. 341 (1-3), 227-239.

El-Sheikh, M. A.; Abbadi, G. A. and ALatar, A. A. (2013). Phytosociological behaviour and mineral allocation in Panicum turgidum Forssk. along the 
coast of the Arabian Gulf, Kuwait. Wiley Editing Services, vol. 123, issu. 3: 177-192.

Flathman, P.E. and Lanza, G.R. (1998). Phytoremediation: current views on an emerging green technology. Journal of Soil Contamination. 7: 415-432.

Garcia, G., A. Faz and M. Cunha, 2004. Performance of Piptatherum miliaceum (Smilo grass) in edophic $\mathrm{Pb}$ and $\mathrm{Zn}$ phytoremediation over a short growth periods. Int. Biodeters. Biodeg., 54: 245-250.

Gupta, S., S. Nayek, R.N. Saha and S. Satpati, 2008. Assessment of heavy metal accumulation in macrophyte, agricultural soil and crop plants adjacent to discharge zone of sponge iron factory. Environ. Geol., 55: 731-739.

Hambidge,M.(2000).Human zinc deficiency.Journal of nutrition . 130: 1344S-1349S.

Humphries ,E. C. (1965 ). Mineral components and ash analysis in modern methods of plant analysis . By Peach,K. and Trace, M. v. , Vol.1, 468-502.

Khairia, M. A. (2012). Assessment of Heavy Metals Accumulation in Native Plant Species from Soils Contaminated in Riyadh City, Saudi Arabia. Life Science Journal 2012;9(2).

Lasat, M. M. ( 2002 ) . Phytoextraction of toxic metals. A review of biological mechanisms. J. Environ. Quality .31 : 109-120 .

Mazhoudi, S., A. Chaouhi, M.H. Ghorbal \& E. Elferjani (1997). Response of antioxidant enzymes to excess copper in tomato (Lycopersicon esculentum, Mill.). Plant Science 127: 129-137

McGrath SP, Zhao FJ (2003). Phytoextraction of metals and metalloids from contaminated soils. Curr Opin Biotechnol 14:277-282.

Prasad, M. N.(2004 ). Metal hyperaccumulation in plants - Biodiversity prospecting for phytoremediation technology. Electronic Journal of Biotechnology, vol. 6 (3). ISSN: 0717-3458

Webber J (1972) Effects of toxic metals in sewage on crops. Water Pollut Control 71:404-

Whiting, A. ; R. D. Reeves and A. J. Baker ( 2002 ) . Mining metallophytes and land reclamation. Mining Environmental Management ,11: 12-16.
Zhao, K., Liu, X., Xu, J., and Selim, H. (2000). Heavy metal contaminations Water research. 33 (3):741750. 